\title{
Phenolic Composition and Antioxidant and Antimicrobial Activities of Extracts Obtained from Crataegus azarolus L. var. aronia (Willd.) Batt. Ovaries Calli
}

\author{
Radhia Bahri-Sahloul, ${ }^{1}$ Radhia Ben Fredj, ${ }^{2}$ Naima Boughalleb, ${ }^{3}$ Jihène Shriaa, \\ Saâd Saguem, ${ }^{2}$ Jean-Louis Hilbert, ${ }^{5}$ Francis Trotin, ${ }^{6}$ \\ Saida Ammar, ${ }^{1}$ Sadok Bouzid, ${ }^{1}$ and Fethia Harzallah-Skhiri ${ }^{7}$ \\ ${ }^{1}$ UR Morphogenesis and Plant Biotechnology Research Unit (UR/09-11), Faculty of Science Tunis, Campus Universitaire, \\ 1060 Tunis El Manar, Tunisia \\ ${ }^{2}$ Metabolic Biophysics and Applied Pharmacology Laboratory, Department of Biophysics, Faculty of Medicine of Sousse, \\ University of Sousse, 4000 Sousse, Tunisia \\ ${ }^{3}$ Laboratory of Plant Pathology, Higher Institute of Agronomy of Chott Mariem, 4042 Sousse, Tunisia \\ ${ }^{4}$ Laboratory of Environment Microbiology, Faculty of Pharmacy, 5000 Monastir, Tunisia \\ 5 "Abiotic Stress and Cultivated Plants Differentiation" UMR1281 USTL, INRA, IFR147, Lille 1 University of Sciences and Technology, \\ SN2 Building, 59655 Villeneuve d'Ascq Cedex, France \\ ${ }^{6}$ Pharmacognosy Laboratory, Faculty of Pharmacy, BP 83, 59006 Lille, France \\ ${ }^{7}$ Laboratory of Genetics Biodiversity and Valorisation of Bioressources (LR11ES41), Higher Institute of Biotechnology, \\ Rue Tahar Haddad, 5000 Monastir, Tunisia
}

Correspondence should be addressed to Radhia Bahri-Sahloul; bahriradhia@yahoo.fr

Received 21 August 2013; Accepted 9 December 2013; Published 20 January 2014

Academic Editor: Muhammad Y. Ashraf

Copyright (c) 2014 Radhia Bahri-Sahloul et al. This is an open access article distributed under the Creative Commons Attribution License, which permits unrestricted use, distribution, and reproduction in any medium, provided the original work is properly cited.

Objective. Plant cell culture is an innovative technology to produce a variety of substances. Numerous plants synthesize among their secondary metabolites phenolic compounds which possess antioxidant and antimicrobial effects. Hawthorn (Crataegus) is one of these plants which has long been used in folk medicine and is widely utilized in pharmaceutical preparations mainly in neuro- and cardiosedative actions. Methods and Results. The production of polyphenol by fifty-two-week-old Crataegus azarolus var. aronia calli was studied in relation to growth variation and antioxidant and antimicrobial capacity within a subcultured period. The DPPH and $\mathrm{ABTS}^{+}$assays were used to characterize the antioxidant actions of the callus cultures. Antimicrobial activity was tested by using disc diffusion and dilution assays for the determination of the minimal inhibitory concentration (MIC) and the minimal bactericidal concentration $(\mathrm{MBC})$ values of each active extract. High $\mathrm{TEAC}_{\mathrm{DPPH}}, \mathrm{TEAC}_{\mathrm{ABTS}}$, and antimicrobial activity was observed when maximal growth was reached. An optimum of total phenol, proanthocyanidins, flavonoid, (-)-epicatechin, procyanidin B2, chlorogenic acid, and hyperoside was produced during this period. Conclusion. Antioxidant and antimicrobial activities were strongly correlated with total phenols and total flavonoids. Crataegus azarolus var. aronia cells culture represents an important alternative source of natural antioxidants and antimicrobials.

\section{Introduction}

In recent years considerable attention has been devoted to medicinal plants with antioxidant and antimicrobial properties. The antioxidant properties are commonly postulated to play an important role in preventing diseases caused by oxidative stress, such as cancer, coronary arteriosclerosis, and the ageing processes [1]. Phenolic compounds are known to possess different pharmacological activities among which antioxidant and antimicrobial effects have 
recently received more intention. There is much literature concerning the antioxidant and antimicrobial properties of many species from genus Crataegus L. (hawthorn). The genus Crataegus, known as "Zaarour" in Tunisia, is represented by two species in the flora of Tunisia: C. oxyacanthus ssp. monogyna (Jacq.) Rouy and Camus and Crataegus azarolus L. [2]. Crataegus azarolus is represented by two varieties: Crataegus azarolus var. aronia (Willd.) Batt. and C. azarolus var. eu-azarolus Maire; they differ by the color of fruit: yellow fruits for the former and red ones for the latter.

The chemistry and pharmacology of hawthorn is well documented [3-13]. Hawthorn preparations have been used for their sedative actions [14] to treat the early stages of congestive heart failure $[15,16]$ and to reduce blood pressure and total plasma cholesterol [17]. Oral administration of standardized extracts induces a significant decrease in mortality after ischemia reperfusion in animals [15]. The pharmacological effects were ascribed to its polyphenolics among which (-)-epicatechin, proanthocyanidins (procyanidin dimers B1, $\mathrm{B} 2$, and $\mathrm{B} 5$, trimer $\mathrm{C}$, oligomers, and polymers), and flavonoids (hyperoside, vitexin-2" -O-rhamnoside, vitexin$4^{\prime}$-acetyl-2 ${ }^{\prime}$-rhamnoside, spiraeoside, rutin, isoquercitrin, and vitexin) are the most prominent constituents [3-10, 18]. Many of these phenolics have already been studied for their antioxidant functions $[3,4,6,9,18-21]$ and antimicrobial effects [22-24].

Cell cultures represent an alternative source for producing natural antioxidants and antimicrobial compounds. Plant tissue cultures produce a variety of secondary metabolites, sometimes in higher percentage than the original plant, and particularly in the polyphenolic class, high yields have sometimes been obtained [25]. Previous studies showed an interesting polyphenolic production in Crataegus monogyna Jacq. callus and cell suspension cultures [3,26-30] in Crataegus $\times$ sinaica Boiss [31]. Despite the extensive use of the different species of hawthorns, there are no studies on the polyphenolic production in Crataegus azarolus. The aim of this work was the production of phenolics in tissue culture of Crataegus azarolus L. var. aronia ovaries and the investigation of the antioxidant capacity and antimicrobial effects of those metabolites.

\section{Materials and Methods}

2.1. Chemicals. ABTS 2,2-azino-bis (3-ethylbenzothia-zoline-6-sulfonate) and DPPH 2,2-diphenyl-picrylhydrazyl were purchased from Sigma (St. Louis, MO, USA), Trolox C (6-hydroxy-2,5,7,8-tetramethychroma-2carboxylic acid) was purchased from Sigma-Aldrich (Deisenhofen, Germany), and potassium sulphate (di-potassium peroxdisulfate), HPLC grade of (-)-epicatechin, procyanidin dimer B2, chlorogenic acid, hyperoside, rutin, spiraeoside, and isoquercetrin were obtained from Sigma-Aldrich (Taufkirchen, Germany). HPLC grade of cyanidin chloride was obtained from Ex-trasynthèse (Genay, France). HPLC solvents were of HPLC grade. All other reagents used were of analytical grade.
2.2. Plants Material and Sterilization. Floral buds were collected in March 2005 from Crataegus azarolus var. aronia native trees spreading out in the region of HammamSousse (Tunisian Center-Est, semi-arid climatic conditions). A voucher specimen was deposited in the Higher Institute of Agronomy of Chott-Meriem, Botanic Laboratory Herbarium, and was assigned a corresponding number R412 [18]. The explants were washed in soapy water, rinsed under running tap water for approximately $10 \mathrm{~min}$, and subsequently stirred in mercury chloride $(0.1 \%)$ for $5 \mathrm{~min}$ and in sodium hypochlorite $(0.5 \%)$ for $20 \mathrm{~min}$. Finally floral buds were rinsed with sterilized distilled water three times under laminar flow hood. Excess water was removed with sterile filter paper; floral buds were deprived of sepals, petals, and stamens. The upper part of the gynoecium constituted by 2 to 3 carpels was decapitated and the under part (ovaries) was placed in sterile Petri dishes ( $90 \mathrm{~mm}$ diameter) containing $25 \mathrm{~mL}$ nutrient medium solidified by $7 \mathrm{~g} / \mathrm{L}$ agar.

The culture medium contained $\mathrm{B}_{5}$ Gamborg mineral solution elements [32], sucrose $(30 \mathrm{~g} / \mathrm{L})$, myo-inositol $(100 \mathrm{mg} / \mathrm{L})$, pyridoxine $(0.5 \mathrm{mg} / \mathrm{L})$, nicotinic acid $(0.5 \mathrm{mg} / \mathrm{L})$, thiamine $(0.5 \mathrm{mg} / \mathrm{L})$, kinetin $(0.5 \mathrm{mg} / \mathrm{L})$, and $2,4 \mathrm{D}(2 \mathrm{mg} / \mathrm{L})$ $[3,33]$ for callus initiation. The $\mathrm{pH}$ was adjusted to 5.6 before autoclaving. Calli were initiated in the dark for 6 weeks at $23 \pm 2^{\circ} \mathrm{C}$. Experiment was performed with three replications (4 explants/Petri dishes) total number of explants for each replication was 32 .

2.3. Establishment of the In Vitro Callus Cultures. Calli initiated were subcultured ( 6 subcultures) on the same medium under 16:8 light/dark period under a light intensity of $15 \mathrm{~W} \cdot \mathrm{m}^{-2}$ (fluorescent light tubes "Deluxe Cool White") with intervals of 4 weeks. The red color of callus was the qualitative parameter for better production of polyphenols [3]. So, red induced calli were subcultured (7 subcultures) in the same medium under permanent light with intervals of 4 weeks. Growth and production of polyphenols by the fiftytwo-week-old Crataegus azarolus var. aronia calli have been studied within 40 days subculture period. A sample of calli was harvested every 4 days for 40 days, gently pressed on filter paper to remove excess water and their fresh weights (FWs) were recorded. After that they were dried in $80^{\circ} \mathrm{C}$ and their dry weights (DWs) were recorded.

2.4. Preparation of Methanolic Extracts. $2 \mathrm{~g}$ of fresh calli, harvested at days $4,8, \ldots$, and 40 , was transferred to a vial and $30 \mathrm{~mL}$ of methanol was added at room temperature and left to macerate for 3 days to obtain the methanolic extracts, from which the solvent was evaporated using a rotary vacuum evaporator and stored at $4^{\circ} \mathrm{C}$.

\subsection{Colorimetric Analysis}

2.5.1. Analysis of Total Phenols. The concentration of total phenols in each extract was measured by UV spectrophotometry (Jenway 6300) based on a colorimetric oxidation/reduction reaction. The oxidizing agent used was FolinCiocalteu reagent (Merck) [34]. To $50 \mu \mathrm{L}$ of diluted extract 
$(1 \mathrm{mg} / 1 \mathrm{~mL}$ of methanol) was added, in screw-capped test tubes, $750 \mu \mathrm{L}$ of distilled water-Folin-Ciocalteu solution $(28 / 2$ $\mathrm{v} / \mathrm{v})$. After $3 \mathrm{~min}, 200 \mu \mathrm{L}$ of sodium carbonate $\left(\mathrm{Na}_{2} \mathrm{CO}_{3}\right)$ $(200 \mathrm{~g} / \mathrm{L})$ was added and the test tubes were properly shacked before incubating in boiling water bath for $1 \mathrm{~min}$. The tubes were then allowed to cool in the dark. The absorbance was measured at $765 \mathrm{~nm}$ and results were expressed in $\mathrm{mg}$ of gallic acid/100 g dry weight (DW) using appropriate standard curve. For a control sample, $50 \mu \mathrm{L}$ of methanol was used.

2.5.2. Analysis of Proanthocyanidins. The proanthocyanidins were determined by UV spectrophotometry method based on acid hydrolysis and color formation. The HCl/butan-1ol assay was used to quantify the total proanthocyanidins [35]. One $\mathrm{mg}$ of the extract was dissolved in $1 \mathrm{~mL}$ of methanol. To $0.25 \mathrm{~mL}$ of this solution was added $3 \mathrm{~mL}$ of a $95 \%$ solution of $n$-Butanol/HCl $(95 / 5, \mathrm{v} / \mathrm{v})$ in glass stoppered test tubes followed by addition of $0.1 \mathrm{~mL}$ of a solution of $\mathrm{NH}_{4} \mathrm{Fe}\left(\mathrm{SO}_{4}\right)_{2} \cdot 12 \mathrm{H}_{2} \mathrm{O}$ in $2 \mathrm{M} \mathrm{HCl}(0.2 \%$, w/v). The tubes were incubated for $40 \mathrm{~min}$ at $95^{\circ} \mathrm{C}$. For a control sample, $0.25 \mathrm{~mL}$ of methanol was used. After incubation, the samples were cooled and analyzed by measuring absorbance at $540 \mathrm{~nm}$. The results were expressed as $\mathrm{mg}$ of cyanidin chloride/100 g DW.

2.5.3. Analysis of Total Flavonoids. The $\mathrm{AlCl}_{3}$ method [36] was adapted for the purpose of determining the total flavonoid content of the ethyl acetate fractions. $0.5 \mathrm{mg}$ of the extract was dissolved in $1 \mathrm{~mL}$ of methanol. To $0.5 \mathrm{~mL}$ of this solution was added equal volumes of a solution of $2 \% \mathrm{AlCl}_{3} \cdot 6 \mathrm{H}_{2} \mathrm{O}$ (2 $\mathrm{g}$ in $100 \mathrm{~mL}$ methanol). The mixture was thoroughly mixed and incubated for $10 \mathrm{~min}$. After incubation, the samples were cooled and analyzed by measuring absorbance at $367.5 \mathrm{~nm}$. The results were expressed in $\mathrm{mg}$ rutin equivalents/100 g DW.

2.5.4. High Performance Liquid Chromatography Analysis. HPLC analysis of extracts was carried out using a Hewlett Packard 1500 series (Waldbronn, Germany) liquid chromatography system equipped with a vacuum degasser, quaternary pump, autosampler, thermo stated column compartment, and diode array detector. After filtration on millipore filter paper $(0.22 \mu \mathrm{m})$ (Whatman), $20 \mu \mathrm{L}$ methanol extract was injected on a Spherisorb ODS2 RP18 $(5 \mu \mathrm{m})$ reversed phase, and C18 column $(4.6 \mathrm{~mm}$ i.d. $\times 150 \mathrm{~mm}$ ) (Sigma-Aldrich, Taufkirchen, Germany) was eluted by an acidified acetonitrile-water gradient. Elution with a flow rate of $0.7 \mathrm{~mL} / \mathrm{min}$ at $25^{\circ} \mathrm{C}$ was as follows: $0-5 \mathrm{~min}, 0-7.5 \% \mathrm{~B}$ in A; 5-13 min, $20 \%$ B in A; $13-20 \mathrm{~min}, 80 \%$ B in A; 20-25 min, $100 \% \mathrm{~B}$ in $\mathrm{A}$ (solvent $\mathrm{A}$ : acetoni-trile/water, $1 / 9 \mathrm{v} / \mathrm{v}, \mathrm{pH} 2.5$; solvent B: acetonitrile/water, 9/1 v/v, $\mathrm{pH} 2.5$ ).

Phenolic compounds in the methanolic extract were identified by comparison with authentic standards at $360 \mathrm{~nm}$ and at $280 \mathrm{~nm}$. The wavelength changes automatically in 10 minutes.

\subsection{Colorimetric Radical Scavenging Tests}

2.6.1. DPPH Radical Scavenging Activity. Twenty $\mu \mathrm{L}$ of diluted callus extract $(1 \mathrm{mg} / \mathrm{mL}$ using methanol) was added to $980 \mu \mathrm{L}$ of DPPH radical ( $90 \mu \mathrm{M}$ in methanolic solution) in a test tube. Methanol was used in the place of antioxidant solution as a blank. The solution was immediately mixed vigorously for $10 \mathrm{~s}$ by a vortex mixer and transferred to the cuvette holder of the spectrophotometer against the blank, which did not contain the extract. After a 30 min incubation period at room temperature, the absorbance was read against a blank at $515 \mathrm{~nm}$. All experiments were performed in triplicate.

2.6.2. ABTS Radical Scavenging Activity. ABTS radical scavenging activity was measured using a modified Re et al. 1999 method [37]. ABTS radical cation $\left(\mathrm{ABTS}^{+}\right)$was produced by reacting $7 \mathrm{mM}$ aqueous solution of ABTS with $2.45 \mathrm{mM}$ potassium persulfate (final concentration). The reaction mixture was allowed to stand in the dark at room temperature for 12-16 h prior to use.

ABTS $^{+}$solution was diluted with methanol to an absorbance of $0.70 \pm 0.02$ at $734 \mathrm{~nm}$. To a diluted $\mathrm{ABTS}^{+}$ solution $(980 \mu \mathrm{L})$ was added $20 \mu \mathrm{L}$ of the extract solution $(1 \mathrm{mg} / \mathrm{mL}$ of methanol). The solution was immediately mixed vigorously for $10 \mathrm{~s}$ by a vortex mixer and transferred to a cuvette. The absorbance was monitored at $734 \mathrm{~nm}$ after $6 \mathrm{~min}$.

2.6.3. Radical Scavenging Expression. For the two tests (DPPH and ABTS), Trolox, a water-soluble analogue of $\alpha$-tocopherol, (vitamin E) was served as a standard. A concentration-response curve, for $\operatorname{ABTS}^{+}(734 \mathrm{~nm})$ and for DPPH $(515 \mathrm{~nm})$, as a function of different Trolox concentrations was prepared. The decrease in absorption of tested samples was used for calculating the TEAC (Trolox Equivalent Antioxidant Capacity) (TEAC $\mathrm{ABTS}_{\mathrm{A}}$ and $\left.\mathrm{TEAC}_{\mathrm{DPPH}}\right)$. All experiments were performed in triplicate. Results were expressed in $\mu \mathrm{mol}$ Trolox/100 g DW.

\subsection{Antimicrobial Activity}

\subsubsection{Antibacterial Activities}

Bacterial Strains. Both cocci Gram-positive and Gramnegative rods bacterial species were selected as test microorganisms according to their pathologic origin. Staphylococcus aureus (ATCC 29213), Staphylococcus epidermidis (NCIMB 8853), Escherichia coli (ATCC 35218), Pseudomonas aeruginosa (ATCC 27853), Micrococcus luteus (NCIMB8166), and hospital Salmonella typhimurium were used.

Preparation of Inoculums. Mueller-Hinton (M-H) broth was inoculated aseptically with the appropriate microorganisms, $24 \mathrm{~h}$ before testing. This is to ensure that bacteria are perfectly suited to the broth and reached the stationary phase of growth. The inoculated bacterial strains were incubated at $37^{\circ} \mathrm{C}$ during $18-24 \mathrm{~h}$, the inoculum suspension containing 
approximately 105 colony forming units $(\mathrm{CFU}) / \mathrm{mL}$ of bacteria.

Antibacterial Activity Test. The qualitative and quantitative antibacterial assay of extracts was carried out by the disc diffusion method [38]. Five hundred $\mu \mathrm{L}$ of the inoculums were spread over plates containing sterile $\mathrm{M}-\mathrm{H}$ agar $(\mathrm{pH}$ 7.2) and the paper filter discs $(5 \mathrm{~mm})$ were impregnated with $20 \mu \mathrm{L}$ of extract $(10 \mathrm{mg} / \mathrm{mL}$ methanol) dried and placed on the surface of the media. The plates were incubated at $37^{\circ} \mathrm{C}$ for $18 \mathrm{~h}$. The inhibition zone around the disc was measured. Antibacterial tests were performed in triplicate. Two controls were also included in the test. The first was a control with methanol involving the presence of microorganisms but the absence of the test material and the second is a standard antibiotic (Ampicillin; $10 \mu \mathrm{g} / \mathrm{disc}$ ) which was used in order to control the sensitivity of the tested microorganisms. The estimation of the minimal inhibitory concentration (MIC) and minimal bactericidal concentration (MBC) was carried out by the broth dilution method [39]. Dilutions of the extracts were prepared as follows: 5,10 , and $15 \mathrm{mg} / \mathrm{mL}$ of methanol. The $\mathrm{M}-\mathrm{H}$ broth employed for sample dilution was supplemented with tween 80 (Merck, Germany) at a concentration of $5 \%[40,41]$ to enhance extract solubility. MIC values were taken as the lowest extract concentration that prevent visible bacterial growth after $24 \mathrm{~h}$ of incubation at $37^{\circ} \mathrm{C}$, and $\mathrm{MBC}$ as the lowest concentration that completely inhibited bacterial growth. Each experiment was repeated three times. To confirm the results of $\mathrm{MBC}, 10 \mathrm{~mL}$ of the experimental suspensions was subcultured in Trypto-Caseine-soja (TCS) agar plates which were incubated at $37^{\circ} \mathrm{C}$ for $18-24 \mathrm{~h}$ [42].

\subsubsection{Antifungal Activity}

Test Organisms. Four phytopathogenic fungal species were used for the antifungal testing, namely, Fusarium oxysporum, Aspergillus niger, Penicellium sp., and Alternaria sp. These were obtained from the laboratory of phytopathology at the Regional Pole of Agricultural Research and Development in the eastern centre of Chott Mariem, Sousse, Tunisia.

Determination of Antifungal Activity of Extracts. The disc diffusion method was used for antifungal screening [43]. Fungal broth culture aliquots adjusted to 104-105 CFU/mL were added to Potato Dextrose Agar medium and distributed uniformly in $9 \mathrm{~cm}$ Petri plates. Under aseptic conditions, paper discs (6 mm, Whatman no. 1 filter paper) were impregnated with $20 \mu \mathrm{L}$ of extract at $5 \mathrm{mg} / \mathrm{mL}(100 \mu \mathrm{g} /$ disc $)$ and placed on the culture plates after removing the solvent by evaporation. The antifungal agent, Carbendazine $(0.5 \mathrm{mg} / \mathrm{mL})$, was used as a positive control and methanol as a negative control. The diameter of the zone of inhibition $(\mathrm{mm})$ around the disc was measured after incubation at $28^{\circ} \mathrm{C}$ for 4 days and compared with control. The test was performed in triplicate.

2.8. Statistical Analysis. Simple regression analysis was performed to calculate the dose-response relationship of standard solutions used for calibration as well as test samples.
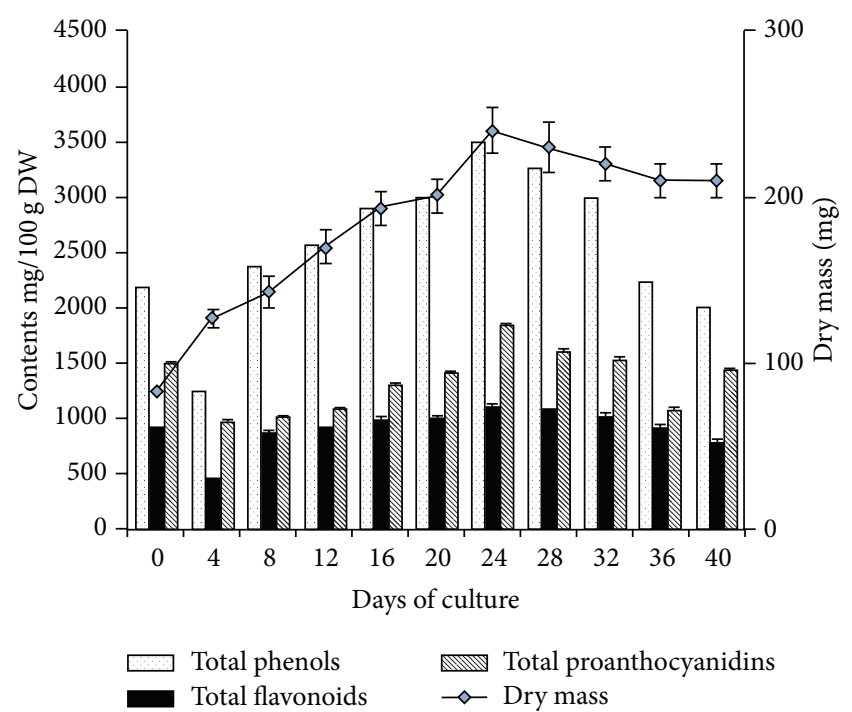

FIGURE 1: Total phenols, total flavonoids, and total proanthocyanidins production by Crataegus azarolus var. aronia ovaries callus cultures versus growth increase.

Linear regression analysis was performed, quoting the correlation coefficient $r_{x y}$ between antioxidant and antibacterial activities and phenolic classes and compounds. All results are expressed as mean value \pm standard deviation of three parallel measurements. The results were processed using Microsoft Excel 2007 and the data were subjected to one way analysis of variance (ANOVA) and the significance of differences between sample means was calculated by Duncan multiple range test using SPSS for Windows (Standard Version 12.0 SPSS Inc., Chicago, IL.); $P$ values $\leq 0.05$ were regarded as significant and $P \leq 0.01$ as very significant.

\section{Results}

3.1. Polyphenols of Crataegus azarolus var. aronia Callus Cultures. Callus cultures initiated from ovaries after 6 weeks were maintained over a period of 52 weeks by 13 subcultures. To study the optimal period for polyphenol synthesis in relation with growth, stabilized callus cultures were analyzed within a culture period of 40 days with every 4 days analysis.

The production of polyphenols in relation to growth is presented in Figure 1. Optimum growth increase was observed from days 16 to $40(190 \pm 10-210 \pm 11 \mathrm{mg}$ DW $)$ with the highest mass production at day $24(240 \pm 12 \mathrm{mg} \mathrm{DW})$. The highest level of total phenols appeared at day 24 with $3500.75 \pm 25.3 \mathrm{mg} / 100 \mathrm{~g}$ DW. Maximal total proanthocyanidin production was recorded between the 24th and 36th day of culture $(1845.69 \pm 35.3$ and $1085.69 \pm 25.6 \mathrm{mg} / 100 \mathrm{~g} \mathrm{DW})$. Rates in flavonoids production are almost identical between the 8th and the 40th day of culture $(857.0 \pm 23.4-765.5 \pm$ $25.36 \mathrm{mg} / 100 \mathrm{~g}$ DW). Maximal production of total flavonoids was recorded in the 24th day of culture with $1100.25 \pm$ $12.3 \mathrm{mg} / 100 \mathrm{DW}$. 
HPLC data (Figure 1) shows that the fifty-two-weekold callus cultures produced mainly chlorogenic acid, (-)epicatechin, proanthocyanidins dimer B2, hyperoside, rutin, spiraeoside, and isoquercitrin. All compounds were at high levels in the beginning of the culture. The highest level was for (-)-epicatechin, followed by chlorogenic acid, procyanidin dimer B2, hyperoside, rutin, spiraeoside and isoquercitrin. Those levels decreased at day 4 , after that all levels increased until day 24. Production of the polyphenols compounds decreased again.

The HPLC analysis of individual compounds (Table 1) shows a relation between the respective yields in the major catechin produced: (-)-epicatechin and procyanidin B2 dimer, as both have the same production profiles with maximum amounts at day 24, (-)-epicatechin: $687.69 \pm$ $13 \mathrm{mg} / 100 \mathrm{~g}$ DW, procyanidin B2: $288.69 \pm 6 \mathrm{mg} / 100 \mathrm{~g}$ DW. In cases, a similar decrease and increase was recorded of both compounds in the same age of culture. A similar observation was previously made $[3,29]$, showing consistency in the phenolic synthesis for the same type of calli. This correlation between dimer B2 and (-)-epicatechin production is consistent with literature data showing that (-)-epicatechin-rich plant organs generally contain procyanidin B2 as the major dimer [3, 29].

Chlorogenic acid, the main phenolic acid, reached a peak level at day $24(400.58 \pm 12.7 \mathrm{mg} / 100 \mathrm{~g}$ DW dry weight $)$ before failing to $265.89 \pm 11.3 \mathrm{mg} / 100 \mathrm{~g} \mathrm{DW}$ dry weight at the end of the culture. As shown in Figure 1 and Table 1, the main flavonoid compounds detected were hyperoside, rutin, spiraeosid, and isoquercitrin with maximum amounts at day $24,136.5 \pm 6 \mathrm{mg} / 100 \mathrm{~g} \mathrm{DW}, 94.6 \pm 3.6 \mathrm{mg} / 100 \mathrm{~g} \mathrm{DW}, 95.57 \pm$ $7 \mathrm{mg} / 100 \mathrm{~g}$ DW, and $58.7 \pm 4 \mathrm{mg} / 100 \mathrm{~g} \mathrm{DW}$, respectively.

\subsection{Antioxidant Capacity of Crataegus azarolus var. aronia} Callus Extracts. The DPPH and $\mathrm{ABTS}^{+}$assays were used to characterize the antioxidant capacity of the callus cultures. The TEAC $\mathrm{DPPH}_{\mathrm{DP}}$ and $\mathrm{TEAC}_{\mathrm{ABTS}}$ were investigated within 40 days culture period with four-day-analysis interval (Table 2). A decrease in TEAC $_{\mathrm{DPPH}}$ and $\mathrm{TEAC}_{\mathrm{ABTS}}$ values was observed at the early stages of culture (days $0-16$ ). The antioxidant capacity increased after this period to attain its highest value at day $24\left(3226.02 \pm 11.7 \mu \mathrm{mol} / 100 \mathrm{~g} \mathrm{DW}\right.$ of TEAC $\mathrm{DPPH}_{\mathrm{D}}$ and $6741.12 \pm 11.4 \mu \mathrm{mol} / 100 \mathrm{~g} \mathrm{DW}$ of $\left.\mathrm{TEAC}_{\mathrm{ABTS}}\right)$. The day 24 to day 36 period corresponds to the maximal production stage of total phenols, flavonoids, proanthocyanidins, (-)epicatechin, procyanidin B2 dimer, hyperoside, rutin, spiraeosid, and isoquercitrin which could positively influence the observed activities. These results are consistent with those obtained previously by $[3,29]$ which demonstrate a high TEAC of Crataegus monogyna callus culture.

In rationalizing the antioxidant potential of the calli in terms of phenolic classes or individual phenolic compounds, it became clear from the regression coefficient data (Table 3 ) that the antioxidant capacity based on $\mathrm{TEAC}_{\mathrm{DPPH}}$ and $\mathrm{TEAC}_{\mathrm{ABTS}}$ was associated more strongly with total phenol $\left(r_{\mathrm{DPPH}}=0.98, r_{\mathrm{ABTS}}=1.00\right)$ and with total flavonoids $\left(r_{\mathrm{DPPH}}=0.97, r_{\mathrm{ABTS}}=0.96\right)$ and, to a lesser extent, with total proanthocyanidins $\left(r_{\mathrm{DPPH}}=0.83, r_{\mathrm{ABTS}}=0.80\right)$.
Hyperoside $\left(r_{\mathrm{DPPH}}=r_{\mathrm{ABTS}}=0.86\right)$, rutin $\left(r_{\mathrm{DPPH}}=r_{\mathrm{ABTS}}=\right.$ $0.76)$, spiraeosid $\left(r_{\mathrm{DPPH}}=0.76, r_{\mathrm{ABTS}}=0.83\right)$, isoquercitrin $\left(r_{\mathrm{DPPH}}=0.77, r_{\mathrm{ABTS}}=0.76\right)$, and chlorogenic acid $\left(r_{\mathrm{DPPH}}=\right.$ $0.75, r_{\mathrm{ABTS}}=0.72$ ) strongly influenced antioxidant efficacy of ovaries calli extracts. (-)-Epicatechin $\left(r_{\mathrm{DPPH}}=0.62\right.$, $\left.r_{\mathrm{ABTS}}=0.67\right)$ and procyanidin $\mathrm{B} 2 \operatorname{dimer}\left(r_{\mathrm{DPPH}}=r_{\mathrm{ABTS}}=\right.$ $0.69)$ influenced lesser antioxidant efficacy. This was reflected by the high correlation coefficients in the TEAC $\mathrm{DPPH}_{\mathrm{DP}}$ and TEAC $_{\mathrm{ABTS}}$ assays (Table 3). Both $\mathrm{TEAC}_{\mathrm{DPPH}}$ and $\mathrm{TEAC}_{\mathrm{ABTS}}$ assays show similar trend in antioxidant potentialities.

3.3. Antibacterial Capacity of Crataegus azarolus var. aronia Callus Extracts. Table 4 shows the antibacterial potentialities of Crataegus azarolus var. aronia callus extract against Staphylococcus aureus (ATCC 29213), Staphylococcus epidermidis (NCIMB 8853), Escherichia coli (ATCC 35218), Pseudomonas aeruginosa (ATCC 27853), Micrococcus luteus (NCIMB8166), and hospital Salmonella typhimurium. Antimicrobial activity was observed when maximal growth was reached (Days 2428) against only the cocci Gram positive bacteria with an inhibition diameter varying between 10.9 (against Staphylococcus aureus) and $14.5 \mathrm{~mm}$ (against Micrococcus luteus) and a $\mathrm{MIC}=\mathrm{MBC}=625 \mu \mathrm{g} / \mathrm{mL}$ for all bacteria. This higher resistance among Gram negative bacteria could be due to the differences in the cell membrane of these bacterial groups. Indeed, the external membrane of Gram negative bacteria renders their surfaces highly hydrophilic [44], whereas the lipophilic ends of the lipoteichoic acids of the cell membrane of Gram positive bacteria may facilitate penetration by hydrophobic compounds $[45,46]$. According to [39, 4750], aromatic compounds group were known with their important antibacterial activity. The latter has been found to inhibit production of amylase and protease by Bacillus cereus, deteriorate cell wall, and cause cell lysis [51].

3.4. Antifungal Activity. No antifungal activity was observed against the four pathogenic fungi. This result could be due to the low concentration of extract used. Therefore, we recommended the use of higher concentrations of extracts in order to obtain a more potent effect against all microorganisms.

\section{Discussion}

The production of polyphenols by calli cultures varied with age. Polyphenols production by two-year-old callus culture has been studied in relation to growth variation within a 40-day subculture period by [3]. Period of maximum production was found between 24 and 36 days of culture. Maximum contents in total phenol $(5.89 \mathrm{~g} / 100 \mathrm{~g} \mathrm{DW})$, total proanthocyanidins $(2.96 \mathrm{~g} / 100 \mathrm{~g} \mathrm{DW})$, and total anthocyanins $(0.288 \mathrm{~g} / 100 \mathrm{~g} \mathrm{DW})$ were found to be more important than in our results. On the other hand, maximal contents in (-)-epicatechin $(0.838 \mathrm{~g} / 100 \mathrm{~g} \mathrm{DW})$, procyanidin B2 dimer $(0.321 \mathrm{~g} / 100 \mathrm{~g} \mathrm{DW})$, hyperoside $(0.143 \mathrm{~g} / 100 \mathrm{~g} \mathrm{DW})$, and isoquercitrin $(0.020 \mathrm{~g} / 100 \mathrm{~g} \mathrm{DW})$ were detected. Chlorogenic acid was the main phenol acid synthesized by Crataegus monogyna callus culture with an optimal content equal to $0.769 \mathrm{~g} / 100 \mathrm{~g}$ DW (Table 5). 
TABLE 1: Individual phenolic content measured by HPLC in methanolic ovaries calli extracts. Amounts of compounds are given as mean values \pm standard deviation $(n=3)$. Integration of area of individual peaks was compared to their corresponding standard (four points standard curve, $R^{2}$ presented in the table) to calculate the individual phenolic concentration expressed in $\mathrm{mg} / 100 \mathrm{~g}$ DW.

\begin{tabular}{|c|c|c|c|c|c|c|c|}
\hline $\begin{array}{l}\text { Culture } \\
\text { day }\end{array}$ & $\begin{array}{l}\text { Chlorogenic acid } \\
\left(R^{2}=0.9995\right)\end{array}$ & $\begin{array}{c}(-) \text {-Epicatechin } \\
\left(R^{2}=0.9989\right)\end{array}$ & $\begin{array}{c}\text { Procyanidin } \\
\text { dimer B2 } \\
\left(R^{2}=0.9995\right)\end{array}$ & $\begin{array}{l}\text { Hyperoside } \\
\left(R^{2}=0.9974\right)\end{array}$ & $\begin{array}{c}\text { Rutin } \\
\left(R^{2}=0.9981\right)\end{array}$ & $\begin{array}{c}\text { Spiraeoside } \\
\left(R^{2}=0.9924\right)\end{array}$ & $\begin{array}{l}\text { Isoquercitrin } \\
\left(R^{2}=0.9996\right)\end{array}$ \\
\hline 0 & $360.25 \pm 11.2^{\mathrm{h} *}$ & $653.48 \pm 12^{\mathrm{g}}$ & $280.65 \pm 12^{\mathrm{i}}$ & $120.36 \pm 5^{\mathrm{h}}$ & $90.36 \pm 4^{\mathrm{i}}$ & $90.25 \pm 5^{\mathrm{h}}$ & $50.63 \pm 4^{\mathrm{g}}$ \\
\hline 4 & $142.23 \pm 5.2^{\mathrm{a}}$ & $365.78 \pm 10^{\mathrm{bc}}$ & $56.24 \pm 12^{\mathrm{a}}$ & $50.36 \pm 3.5^{\mathrm{a}}$ & $45.12 \pm 3^{\mathrm{a}}$ & $63.47 \pm 3^{b}$ & $25.68 \pm 2^{\mathrm{a}}$ \\
\hline 8 & $150.23 \pm 10.2^{\mathrm{b}}$ & $387.45 \pm 13^{\mathrm{de}}$ & $75.68 \pm 6^{\mathrm{b}}$ & $78.63 \pm 2^{b}$ & $50.78 \pm 4^{\mathrm{c}}$ & $70.58 \pm 4^{\mathrm{c}}$ & $30.86 \pm 2^{b}$ \\
\hline 12 & $164.58 \pm 11.3^{c}$ & $400.58 \pm 17^{\mathrm{e}}$ & $85.69 \pm 6^{c}$ & $80.69 \pm 9^{e}$ & $48.69 \pm 3^{\mathrm{b}}$ & $77.63 \pm 5^{d}$ & $33.56 \pm 2^{c}$ \\
\hline 16 & $180.69 \pm 8.6^{\mathrm{d}}$ & $369.56 \pm 11^{\mathrm{ed}}$ & $90.47 \pm 6^{\mathrm{d}}$ & $88.69 \pm 5^{\mathrm{d}}$ & $55.48 \pm 3^{\mathrm{d}}$ & $89.45 \pm 6^{\mathrm{f}}$ & $30.47 \pm 3^{b}$ \\
\hline 20 & $265.89 \pm 6.8^{\mathrm{e}}$ & $356.78 \pm 10^{\mathrm{b}}$ & $99.58 \pm 6^{\mathrm{e}}$ & $90.56 \pm 4^{\mathrm{e}}$ & $68.74 \pm 5^{\mathrm{e}}$ & $90.86 \pm 6^{\mathrm{g}}$ & $36.87 \pm 3^{e}$ \\
\hline 24 & $400.58 \pm 12.7^{\mathrm{j}}$ & $687.69 \pm 13^{\mathrm{h}}$ & $288.69 \pm 6^{j}$ & $136.54 \pm 6^{\mathrm{i}}$ & $94.58 \pm 3.6^{j}$ & $95.57 \pm 7^{\mathrm{h}}$ & $58.69 \pm 2^{\mathrm{i}}$ \\
\hline 28 & $369.451 \pm 10.8^{\mathrm{i}}$ & $647.56 \pm 13^{k}$ & $230.58 \pm 9^{h}$ & $96.58 \pm 5^{\mathrm{g}}$ & $77.48 \pm 4.5^{\mathrm{h}}$ & $90.34 \pm 7^{g}$ & $55.36 \pm 4^{\mathrm{h}}$ \\
\hline 32 & $300.58 \pm 11.4^{\mathrm{g}}$ & $452.36 \pm 12^{\mathrm{f}}$ & $120.45 \pm 8^{g}$ & $92.36 \pm 3^{\mathrm{f}}$ & $73.89 \pm 5^{\mathrm{g}}$ & $80.56 \pm 6^{e}$ & $50.68 \pm 4^{\mathrm{g}}$ \\
\hline 36 & $280.69 \pm 12.2^{\mathrm{f}}$ & $364.69 \pm 12^{\mathrm{bc}}$ & $110.36 \pm 8^{\mathrm{f}}$ & $88.75 \pm 5^{\mathrm{d}}$ & $70.58 \pm 3.6^{\mathrm{f}}$ & $70.43 \pm 7^{\mathrm{c}}$ & $44.36 \pm 4^{\mathrm{f}}$ \\
\hline 40 & $265.89 \pm 11.3^{\mathrm{e}}$ & $256.47 \pm 10^{\mathrm{a}}$ & $100.45 \pm 6^{\mathrm{ef}}$ & $80.96 \pm 4^{\mathrm{e}}$ & $55.45 \pm 3^{\mathrm{d}}$ & $50.36 \pm 7^{\mathrm{a}}$ & $35.36 \pm 4^{\mathrm{d}}$ \\
\hline
\end{tabular}

* In the same column, values with the same letters are not significantly different at $P \leq 0.01$.

TABLE 2: Antioxidant activity ( $\mu \mathrm{mol}$ Trolox $/ 100 \mathrm{~g} \mathrm{DW}$ ) of ovaries calli extracts of Crataegus azarolus var. aronia within days of culture.

\begin{tabular}{lcc}
\hline Day culture & DPPH & ABTS \\
\hline 0 & $2750.95 \pm 9.23^{\mathrm{g} *}$ & $6576.71 \pm 12.75^{\mathrm{h}}$ \\
4 & $1139.52 \pm 7.41^{\mathrm{a}}$ & $3888.02 \pm 11.17^{\mathrm{a}}$ \\
8 & $2179.72 \pm 11.24^{\mathrm{b}}$ & $3984.53 \pm 12.37^{\mathrm{b}}$ \\
12 & $2361.66 \pm 12.36^{\mathrm{e}}$ & $4708.20 \pm 12.45^{\mathrm{c}}$ \\
16 & $2669.44 \pm 11.47^{\mathrm{f}}$ & $5682.30 \pm 11.11^{\mathrm{d}}$ \\
20 & $2732.54 \pm 8.23^{\mathrm{g}}$ & $5959.34 \pm 10.47^{\mathrm{e}}$ \\
24 & $3226.02 \pm 11.74^{\mathrm{i}}$ & $6741.12 \pm 11.42^{\mathrm{ij}}$ \\
28 & $3000.89 \pm 11.23^{\mathrm{h}}$ & $6412.09 \pm 14.23^{\mathrm{g}}$ \\
32 & $2765.37 \pm 10.47^{\mathrm{g}}$ & $6290.97 \pm 11.32^{\mathrm{f}}$ \\
36 & $2280.04 \pm 11.42^{\mathrm{d}}$ & $6708.89 \pm 9.36^{\mathrm{i}}$ \\
40 & $2215.31 \pm 11.34^{\mathrm{bc}}$ & $6412.30 \pm 8.47^{\mathrm{g}}$ \\
\hline
\end{tabular}

${ }^{*}$ Data shown are the mean \pm standard deviation; in the same column, values with the same letters are not significantly different at $P \leq 0.01$.

Kartnig et al., 1993 [27], studies of flavonoid and procyanidin contents of two-month-old callus cultures from Crataegus monogyna shoot tips cultured in MS medium supplied with NAA/kinetin, showed a more complex and interesting flavonoid pattern with the isolation of vitexin, vitexin-2" -orhamnoside $(0.00456 \mathrm{~g} / 100 \mathrm{~g} \mathrm{DW})$, rutin $(0.002 \mathrm{~g} / 100 \mathrm{~g} \mathrm{DW})$, and hyperoside, the latter being dominant $(0.01258 \mathrm{mg} 100 \mathrm{~g} / \mathrm{dry} w \mathrm{t})$. Maximum total proanthocyanidins content was $0.017 \mathrm{~g} 100 \mathrm{~g} / \mathrm{DW}$ (Table 5).

Rakotoarison et al., 1997 [28], analyzing the five-yearold callus culture initiated by [3] within a 30 -day subculture, found that contents in polyphenolic and in the individual compounds identified decreased. Maximal contents (between 24 and 28 days of culture) in total phenols, flavonoids, and proanthocyanidins reached $2.33,1.3$, and $0.92 \mathrm{~g} / 100 \mathrm{~g} \mathrm{DW}$,
TABLE 3: Correlation coefficients between $\mathrm{TEAC}_{\mathrm{DPPH}} / \mathrm{TEAC}_{\mathrm{ABTS}}$ and phenolic contents of Crataegus azarolus var. aronia ovaries callus culture.

\begin{tabular}{lcc}
\hline & TEAC $_{\mathrm{DPPH}}$ & $\mathrm{TEAC}_{\mathrm{ABTS}}$ \\
\hline Total phenols & 0.98 & 1.00 \\
Total flavonoids & 0.97 & 0.96 \\
Total proanthocyanidins & 0.83 & 0.80 \\
Chlorogenic acid & 0.75 & 0.72 \\
Hyperoside & 0.86 & 0.86 \\
Rutin & 0.76 & 0.76 \\
Isoquercitrin & 0.77 & 0.76 \\
Spiraeoside & 0.76 & 0.83 \\
Epicatechin & 0.62 & 0.67 \\
Procyanidin B2 & 0.69 & 0.69 \\
\hline
\end{tabular}

respectively. (-)-Epicatechin $(0.675 \mathrm{~g} / 100 \mathrm{~g} \mathrm{DW})$, procyanidin B2 $(0.5142 \mathrm{~g} / 100 \mathrm{~g} \mathrm{DW})$, hyperoside $(0.528 \mathrm{~g} / 100 \mathrm{~g} \mathrm{DW})$, and chlorogenic acid $(0.235 \mathrm{~g} / 100 \mathrm{~g} \mathrm{DW})$ were also found (Table 5).

Bahorun et al., 2003 [29], analyzed the polyphenolic composition of ten-year-old callus culture (same initiated culture) within a 45-day subculture. Compared to previous study [3], a quantitative and qualitative different polyphenolic composition was found. Generally lower content in total phenols $(4.74 \mathrm{~g} / 100 \mathrm{~g} \mathrm{DW})$, total proanthocyanidins (2.081 g/100 g DW), (-)-epicatechin (0.177 g/100 g DW), hyperoside (traces), isoquercitrin (absent), and chlorogenic acid $(0.111 \mathrm{~g} / 100 \mathrm{~g}$ DW) was carried. Higher anthocyanins content was detected $(0.618 \mathrm{~g} / 100 \mathrm{~g} \mathrm{DW})$.

Maharik et al., 2009 [31], demonstrate that stem callus culture of C. sinaica produce a high content in anthocyans equal to $157.98 \mu \mathrm{g} / \mathrm{g} \mathrm{FW}$ when culture medium contained $2 \mathrm{mg} / \mathrm{L} \mathrm{BA}$ and $1 \mathrm{mg} / \mathrm{L}$ NAA. 


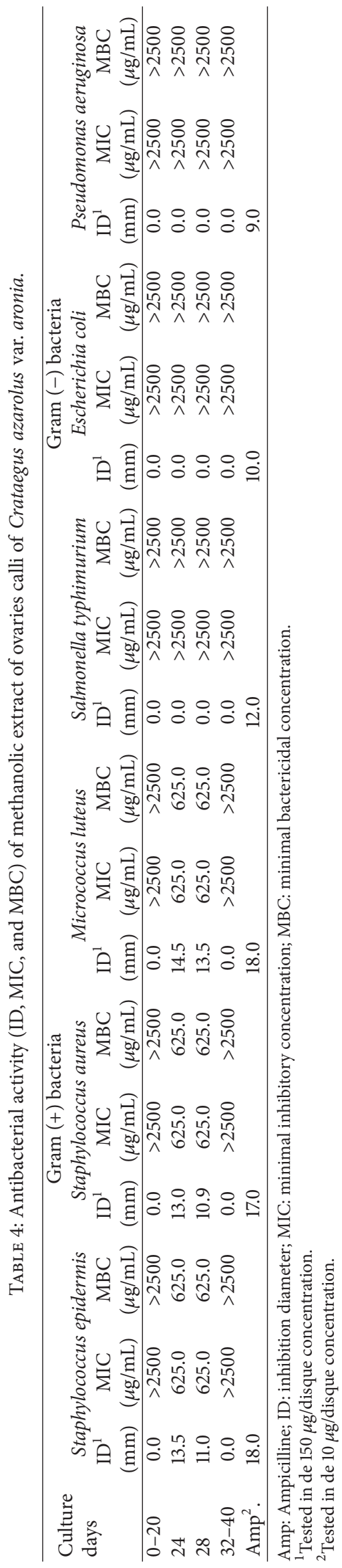


TABle 5: Comparative of maximal phenolic production (g/100 g DW) in Crataegus sp. callus culture within literature.

\begin{tabular}{|c|c|c|c|c|c|}
\hline References & $\begin{array}{c}\text { Kartnig et al., } \\
1993 \text { [27] }\end{array}$ & $\begin{array}{c}\text { Bahorun et al., } \\
1994 \text { [3] }\end{array}$ & $\begin{array}{c}\text { Rakotoarison et al., } \\
1997 \text { [28] }\end{array}$ & $\begin{array}{l}\text { Bahorun et al., } \\
2003 \text { [29] }\end{array}$ & $\begin{array}{c}\text { Maharik et al., } \\
2009[31]\end{array}$ \\
\hline Crataegus species & C. monogyna & C. monogyna & C. monogyna & C. monogyna & C. sinaica \\
\hline Five explants used & Shoot tips & Bud flower & Bud flower & Bud flower & Stem \\
\hline Mineral medium used & MS & Gamborg B5 & Gamborg B5 & Gamborg B5 & MS \\
\hline $\begin{array}{l}\text { Hormones used } \\
\left(\mathrm{mgL}^{-1} / \mathrm{mgL}^{-1}\right)\end{array}$ & NAA/kinetin $(6 / 1)$ & 2.4D/kinetin $(2 / 0.5)$ & $2.4 \mathrm{D} /$ kinetin $(2 / 0.5)$ & 2.4D/kinetin $(2 / 0.5)$ & BAP/NAA $(2 / 1)$ \\
\hline Callus old & Two months & Two-year-old & Five-year-old & Ten-year-old & 6 weeks \\
\hline $\begin{array}{l}\text { Period of maximum } \\
\text { production }\end{array}$ & - & $24-36$ & $24-28$ & $25-35$ & $40-42$ \\
\hline Total phenols & Not determined & 5.890 (day 28) & 2.330 (day 28) & 4.740 (day 35$)$ & Not determined \\
\hline Total flavonoids & Not determined & Not determined & 1.300 (day 28) & 0.701 (day 35) & Not determined \\
\hline Hyperoside & 0.0125 & 0.140 (day 36$)$ & 0.528 (day 24$)$ & Traces & Not determined \\
\hline Isoquercitrin & Not detectable & 0.020 (day 36) & Not determined & Absent & Not determined \\
\hline Quercetin & Not detectable & Absent & Not determined & Present & Not determined \\
\hline Chlorogenic acid & Not detectable & $0.770($ day 24$)$ & 0.235 (day 24$)$ & 0.111 (day 25) & Not determined \\
\hline Anthocyanins & Not detectable & 0.288 (day 28$)$ & Not determined & 0.619 (day 35$)$ & $0.016(\mathrm{mg} / 100 \mathrm{~g} \mathrm{FW})$ \\
\hline Total proanthocyanidins & 0.017 & 2.960 (day 32) & $0.920($ day 28$)$ & 0.2018 (day 35) & Not determined \\
\hline Procyanidin dimer B2 & Not determined & 0.320 (day 24$)$ & 0.514 (day 24$)$ & 0.339 (day 25$)$ & Not determined \\
\hline (-)-Epicatechin & Not determined & 0.840 (day 28) & $0.675($ day 28$)$ & 0.177 (day 25$)$ & Not determined \\
\hline Vitexin-2" -o-rhamnoside & 0.00456 & Not determined & Not determined & Not determined & Not determined \\
\hline Rutin & 0.002206 & Not determined & Not determined & Not determined & Not determined \\
\hline
\end{tabular}

Comparing our results to previous studies [3, 27-29] on Crataegus monogyna and Crataegus sinaica callus cultures [31], we can note that polyphenolic pattern differs both qualitatively and quantitatively. In fact, the polyphenolic composition, the optimum production of phenolic classes and individual constituents within their respective subculture periods, is different and shows fluctuations. These differences can be explained by difference in the Crataegus species, Crataegus organs explants, culture medium, growth regulators used, laboratory culture condition, and the age of callus culture.

Despite the relative difference in contents of phenolic compounds, we constate that our calli produces appreciable amounts of phenolic compounds in comparison to literature data [3, 27-29, 31]. Our calli cultures from Crataegus azarolus var. aronia ovaries remain one of the highest polyphenol producing cell lines on an important time scale (52 weeks).

Concerning antioxidant activity, we have observed rapid and strong inhibition of both DPPH and ABTS radicals after the addition of methanolic extracts from Crataegus azarolus var. aronia ovaries callus showing a high antioxidant activity of those extracts. This is in accordance with [52] studies, where authors demonstrate that hydrogen peroxide $\left(\mathrm{H}_{2} \mathrm{O}_{2}\right)$, hypochlorous acid $(\mathrm{HOCl})$, and superoxide anion $\left(\mathrm{O}_{2}{ }^{\circ-}\right)$ scavenging potency remained low during the early growth period. After day 8 the $\mathrm{IC}_{50}$ values decreased to reach minimal values in the three systems at day 28 with a respective $\mathrm{IC}_{50}$ in $\mathrm{H}_{2} \mathrm{O}_{2}, \mathrm{HOCl}$, and $\mathrm{O}_{2}{ }^{--}$of $17.59,44.52$, and $77.22 \mathrm{mg}$ DW/L.
Rakotarison et al., 1997 [28], demonstrate too that the lowest $\mathrm{IC}_{50}$ was found at the period of the maximal total phenolic production with a respective $\mathrm{IC}_{50}$ in $\mathrm{HOCl}$ and $\mathrm{H}_{2} \mathrm{O}_{2}$ of 48.22 and $13.26 \mathrm{mg} \mathrm{DW} / \mathrm{L}$ at 28 days of culture. Reference [29] suggests that high TEAC $(3.66 \mu \mathrm{mol} / \mathrm{g} \mathrm{DW})$ and FRAP (208.19 $\mu \mathrm{mol} \mathrm{Fe2+/g} \mathrm{DW)} \mathrm{values} \mathrm{were} \mathrm{observed}$ when maximal growth was reached (days 30-35). The TEAC values were strongly associated with total flavonoids and to a lesser extent with total phenols, anthocyanins, and total proanthocyanidins.

Antioxidant activity is correlated with phenolic composition and this seemed to be influenced by phenolic composition and it is in accordance with previous studies [18, $53,54]$, who demonstrated a significant correlation between phenolic composition and antioxidant activity. Reference [53] demonstrates also that coefficient correlation is respectively equal to 0.79 and 0.78 between antioxidant activity and total phenolic and flavonoids composition of Algerian plant extracts. Reference [54] demonstrates a correlation between procyanidins and antioxidant activity while [55] demonstrates that hyperoside and quercetin were antioxidant molecules.

For the antimicrobial activity, antibacterial activity against Gram positive bacteria was observed only when maximal growth was reached (days 24-28). There is no report for the antimicrobial activity of Crataegus sp. callus culture, but other studies demonstrate the antimicrobial activity of Crataegus plant organs extract. Reference [56] demonstrates that ethanolic extract of C. cuneata has an MIC equal to 
$50 \mathrm{mg} / \mathrm{mL}$ against E. coli. Reference [57] demonstrates the antibacterial activity of ethyl acetate extract of $C$. tanacetifolia (Poir.) Pers. against 28 bacteria. Reference [24] demonstrates that ethanolic extracts of C. monogyna, C. pseudoheterophylla, and C. azarolus present an MIC between 128 and $8 \mu \mathrm{g} / \mathrm{mL}$ against Escherichia coli, Pseudomonas aeruginosa, Staphylococcus aureus, and other bacteria. In our study this activity seemed to be influenced by phenolic composition and this is in accordance with previous studies that demonstrate a significant correlation between phenolic composition and antimicrobial activity. In fact [22] demonstrates that quercetin is an antibacterial molecule that can inhibit bacteria lipase production [58] and inhibit d-alanine ligase activity which occurs in peptidoglycans production [59]. Other phenolic compounds are antibacterial such us rutin [60], (-)epicatechin [61], and procyanidin B2 [62]. Some research indicate that antifungal activity is correlated with phenolic compound such us rutin [63], with ursolic acid [64].

\section{Conclusion}

In conclusion, Crataegus azarolus var. aronia ovaries callus culture can be used as a source of natural antioxidant and antimicrobial polyphenolic compounds and it is a new plant source, independent of the season and climate conditions. Further assays should be conducted with a focus on the use of different precursors (shikimic acid, gallic acid, and phenylalanine) to optimize the polyphenolic production by this calli culture and the realization of suspension culture tissue.

\section{Conflict of Interests}

The authors declare that there is no conflict of interests.

\section{References}

[1] H. Haraguchi, T. Saito, N. Okamura, and A. Yagi, "Inhibition of lipid peroxidation and superoxide generation by diterpenoids from Rosmarinus officinalis," Planta Medica, vol. 61, no. 4, pp. 333-336, 1995.

[2] G. Pottier-Alapetite, Flore de la Tunisie. Angiospermes-Dicotylédones. Apétales-Dialypétales, Publications Scientifiques Tunisiennes, 1979.

[3] T. Bahorun, F. Trotin, J. Pommery, J. Vasseur, and M. Pinkas, "Antioxidant activities of Crataegus monogyna extracts," Planta Medica, vol. 60, no. 4, pp. 323-328, 1994.

[4] T. Bahorun, B. Gressier, F. Trotin et al., "Oxygen species scavenging activity of phenolic extracts from hawthorn fresh plant organs and pharmaceutical preparations," ArzneimittelForschung, vol. 46, no. 11, pp. 1086-1089, 1996.

[5] Z. Zhang, Q. Chang, M. Zhu, Y. Huang, W. K. K. Ho, and Z.Y. Chen, "Characterization of antioxidants present in hawthorn fruits," Journal of Nutritional Biochemistry, vol. 12, no. 3, pp. 144152, 2001.

[6] Y. Cai, Q. Luo, M. Sun, and H. Corke, "Antioxidant activity and phenolic compounds of 112 traditional Chinese medicinal plants associated with anticancer," Life Sciences, vol. 74, no. 17, pp. 2157-2184, 2004.
[7] Q. Chang, Z. Zuo, M. S. S. Chow, and W. K. K. Ho, "Effect of storage temperature on phenolics stability in hawthorn (Crataegus pinnatifida var. major) fruits and a hawthorn drink," Food Chemistry, vol. 98, no. 3, pp. 426-430, 2006.

[8] A. Urbonavičiute, V. Jakštas, O. Kornyšova, V. Janulis, and A. Maruška, "Capillary electrophoretic analysis of flavonoids in single-styled hawthorn (Crataegus monogyna Jacq.) ethanolic extracts," Journal of Chromatography A, vol. 1112, no. 1-2, pp. 339-344, 2006.

[9] T. Cui, K. Nakamura, S. Tian, H. Kayahara, and Y.-L. Tian, "Polyphenolic content and physiological activities of Chinese hawthorn extracts," Bioscience, Biotechnology and Biochemistry, vol. 70, no. 12, pp. 2948-2956, 2006.

[10] U. Svedström, H. Vuorela, R. Kostiainen, I. Laakso, and R. Hiltunen, "Fractionation of polyphenols in hawthorn into polymeric procyanidins, phenolic acids and flavonoids prior to high-performance liquid chromatographic analysis," Journal of Chromatography A, vol. 1112, no. 1-2, pp. 103-111, 2006.

[11] A. Sokół-Łetowska, J. Oszmiański, and A. Wojdyło, "Antioxidant activity of the phenolic compounds of hawthorn, pine and skullcap," Food Chemistry, vol. 103, no. 3, pp. 853-859, 2007.

[12] P. Liu, H. Kallio, D. Lü, C. Zhou, and B. Yang, "Quantitative analysis of phenolic compounds in Chinese hawthorn (Crataegus spp.) fruits by high performance liquid chromatographyelectrospray ionisation mass spectrometry," Food Chemistry, vol. 127, no. 3, pp. 1370-1377, 2011.

[13] G. Pan, G. Yu, C. Zhu, and J. Qiao, "Optimization of ultrasoundassisted extraction (UAE) of flavonoids compounds (FC) from hawthorn seed (HS)," Ultrasonics Sonochemistry, vol. 19, no. 3, pp. 486-490, 2012.

[14] M. Hanus, J. Lafon, and M. Mathieu, "Double-blind, randomised, placebo-controlled study to evaluate the efficacy and safety of a fixed combination containing two plant extracts (Crataegus oxyacantha and Eschscholtzia californica) and magnesium in mild-to-moderate anxiety disorders," Current Medical Research and Opinion, vol. 20, no. 1, pp. 63-71, 2004.

[15] M. Veveris, E. Koch, and S. S. Chatterjee, "Crataegus special extract WS 1442 improves cardiac function and reduces infarct size in a rat model of prolonged coronary ischemia and reperfusion," Life Sciences, vol. 74, no. 15, pp. 1945-1955, 2004.

[16] S. R. Long, R. A. Carey, K. M. Crofoot, P. J. Proteau, and T. M. Filtz, "Effect of hawthorn (Crataegus oxycantha) crude extract and chromatographic fractions on multiple activities in a cultured cardiomyocyte assay," Phytomedicine, vol.13, no. 9-10, pp. 643-650, 2006.

[17] A. F. Walker, G. Marakis, A. P. Morris, and P. A. Robinson, "Promising hypotensive effect of hawthorn extract: a randomized double-blind pilot study of mild, essential hypertension," Phytotherapy Research, vol. 16, no. 1, pp. 48-54, 2002.

[18] R. Bahri-Sahloul, S. Ammar, R. B. Fredj et al., "Polyphenol contents and antioxidant activities of extracts from flowers of two Crataegus azarolus L. varieties," Pakistan Journal of Biological Sciences, vol. 12, no. 9, pp. 660-668, 2009.

[19] W. Bors, C. Michel, and K. Stettmaier, "Structure-activity relationships governing antioxidant capacities of plant polyphenols," Methods in Enzymology, vol. 335, pp. 166-180, 2001.

[20] C.-Y. Chu, M.-J. Lee, C.-L. Liao, W.-L. Lin, Y.-F. Yin, and T.-H. Tseng, "Inhibitory effect of hot-water extract from dried fruit of Crataegus pinnatifida on Low-Density Lipoprotein (LDL) oxidation in cell and cell-free systems," Journal of Agricultural and Food Chemistry, vol. 51, no. 26, pp. 7583-7588, 2003. 
[21] P. Ljubuncic, I. Portnaya, U. Cogan, H. Azaizeh, and A. Bomzon, "Antioxidant activity of Crataegus aronia aqueous extract used in traditional Arab medicine in Israel," Journal of Ethnopharmacology, vol. 101, no. 1-3, pp. 153-161, 2005.

[22] T. P. T. Cushnie and A. J. Lamb, "Antimicrobial activity of flavonoids," International Journal of Antimicrobial Agents, vol. 26, no. 5, pp. 343-356, 2005.

[23] P. Cos, A. J. Vlietinck, D. V. Berghe, and L. Maes, "Anti-infective potential of natural products: how to develop a stronger in vitro 'proof-of-concept", Journal of Ethnopharmacology, vol. 106, no. 3, pp. 290-302, 2006.

[24] I. Orhan, B. Özçelik, M. Kartal, B. Özdeveci, and H. Duman, "HPLC quantification of vitexine-2" -O-rhamnoside and hyperoside in three Crataegus species and their antimicrobial and antiviral activities," Chromatographia, vol. 66, no. 1, pp. S153S157, 2007.

[25] H. A. Stafford and T.-Y. Cheng, "The procyanidins of Douglas fir seedlings, callus and cell suspension cultures derived from cotyledons," Phytochemistry, vol. 19, no. 1, pp. 131-135, 1980.

[26] R. Schrall and H. Becker, "Produktion von catechins und oligomeren proanthocyanidinen in callus-und suspensionskulturen von Crataegus monogyna, Crataegus oxyacantha und Ginkgo biloba," Planta Medica, vol. 32, no. 8, pp. 297-307, 1977.

[27] T. Kartnig, G. Kogl, and B. Heydel, "Production of flavonoids in cell cultures of Crataegus monogyna," Planta Medica, vol. 59, no. 6, pp. 537-538, 1993.

[28] D. A. Rakotoarison, B. Gressier, F. Trotin et al., "Antioxidant activities of polyphenolic extracts from flowers, in vitro callus and cell suspension cultures of Crataegus monogyna," Pharmazie, vol. 52, no. 1, pp. 60-64, 1997.

[29] T. Bahorun, E. Aumjaud, H. Ramphul et al., "Phenolic constituents and antioxidant capacities of Crataegus monogyna (Hawthorn) callus extracts," Nahrung, vol. 47, no. 3, pp. 191-198, 2003.

[30] T. Froehlicher, T. Hennebelle, F. Martin-Nizard et al., "Phenolic profiles and antioxidative effects of hawthorn cell suspensions, fresh fruits, and medicinal dried parts," Food Chemistry, vol. 115, no. 3, pp. 897-903, 2009.

[31] N. Maharik, S. Elgengaihi, and H. Taha, "Anthocyanin production in callus cultures of Crataegus sinaica boiss," Academic Research International, vol. 1, no. 1, pp. 30-34, 2009.

[32] O. L. Gamborg, R. A. Miller, and K. Ojima, "Nutrient requirements of suspension cultures of soybean root cells," Experimental Cell Research, vol. 50, no. 1, pp. 151-158, 1968.

[33] Y. Moumou, F. Trotin, J. Vasseur et al., "Procyanidin production by Fagopyrum esculentum callus culture," Planta Medica, vol. 58, no. 6, pp. 516-519, 1992.

[34] V. L. Singleton and J. A. Rossi, "Colorimetry of total phenolics with phosphomolybdic-phosphotngtic acid reagents," American Journal of Enology and Viticulture, vol. 16, no. 3, pp. 144-153, 1965.

[35] L. J. Porter, L. N. Hrstich, and B. G. Chan, "The conversion of procyanidins and prodelphinidins to cyanidin and delphinidin," Phytochemistry, vol. 25, no. 1, pp. 223-230, 1985.

[36] J. L. C. Lamaison and A. Carnat, "Teneurs en principaux flavonoïdes des fleurs et des feuilles de Crataegus monogyna Jacq et de Crataegus laevigata (Poiret) DC, en fonction de la végétation," Plantes Médicinales et Phytothérapies, vol. 25, pp. 12-16, 1990.

[37] R. Re, N. Pellegrini, A. Proteggente, A. Pannala, M. Yang, and C. Rice-Evans, "Antioxidant activity applying an improved ABTS radical cation decolorization assay," Free Radical Biology and Medicine, vol. 26, no. 9-10, pp. 1231-1237, 1999.

[38] A. Marmonier, "Antibiotiques technique de diffusion en gélose méthode des disques," in Bactériologie Médicale Techniques Usuelles, pp. 237-243, SIMEP SA, Paris, France, 1987.

[39] S. Burt, "Essential oils: their antibacterial properties and potential applications in foods-a review," International Journal of Food Microbiology, vol. 94, no. 3, pp. 223-253, 2004.

[40] J. May, C. H. Chan, A. King, L. Williams, and G. L. French, "Time-kill studies of tea tree oils on clinical isolates," Journal of Antimicrobial Chemotherapy, vol. 45, no. 5, pp. 639-643, 2000.

[41] F. Hichri, H. B. Jannet, J. Cheriaa, S. Jegham, and Z. Mighri, "Antibacterial activities of a few prepared derivatives of oleanolic acid and of other natural triterpenic compounds," Comptes Rendus Chimie, vol. 6, no. 4, pp. 473-483, 2003.

[42] R. L. Akins and M. J. Rybak, "Bactericidal activities of two daptomycin regimens against clinical strains of glycopeptide intermediate-resistant Staphylococcus aureus, vancomycinresistant Enterococcus faecium, and methicillin-resistant Staphylococcus aureus isolates in an in vitro pharmacodynamic model with simulated endocardial vegetations," Antimicrobial Agents and Chemotherapy, vol. 45, no. 2, pp. 454-459, 2001.

[43] A. L. Barry and C. Thornsberry, "Susceptibility test: diffusion test procedures," in Manual of Clinical Microbiology, A. B. Hausler, W. J. Herramann, H. D. Isenberg, and H. J. Shadomy, Eds., pp. 1526-1542, American Society for Microbiology, Washington, DC, USA, 1991.

[44] A. Smith-Palmer, J. Stewart, and L. Fyfe, "Antimicrobial properties of plant essential oils and essences against five important food-borne pathogens," Letters in Applied Microbiology, vol. 26, no. 2, pp. 118-122, 1998.

[45] A. Ultee, E. P. W. Kets, and E. J. Smid, "Mechanisms of action of carvacrol on the food-borne pathogen," Applied and Environmental Microbiology, vol. 65, no. 10, pp. 4606-4610, 1999.

[46] S. D. Cox, C. M. Mann, J. L. Markham et al., "The mode of antimicrobial action of the essential oil of Melaleuca alternifolia (Tea tree oil)," Journal of Applied Microbiology, vol. 88, no. 1, pp. 170-175, 2000.

[47] M. Lis-Balchin, S. G. Deans, and E. Eaglesham, "Relationship between bioactivity and chemical composition of commercial essential oils," Flavour and Fragrance Journal, vol. 13, pp. 98-104, 1998.

[48] A. Pauli, "Antimicrobial properties of essential oil constituents," International Journal of Aromatherapy, vol. 11, no. 3, pp. 126-133, 2001.

[49] K. Cimanga, K. Kambu, L. Tona et al., "Correlation between chemical composition and antibacterial activity of essential oils of some aromatic medicinal plants growing in the Democratic Republic of Congo," Journal of Ethnopharmacology, vol. 79, no. 2, pp. 213-220, 2002.

[50] K. Rhayour, T. Bouchikhi, A. Tantaoui-Elaraki, K. Sendide, and A. Remmal, "The mechanism of bactericidal action of oregano and clove essential oils and of their phenolic major components on Escherichia coli and Bacillus subtilis," Journal of Essential Oil Research, vol. 15, no. 5, pp. 356-362, 2003.

[51] J. Thoroski, G. Blank, and C. Biliaderis, "Eugenol induced inhibition of extracellular enzyme production by Bacillus cereus," Journal of Food Protection, vol. 52, no. 6, pp. 399-403, 1989.

[52] T. Bahorun, F. Trotin, and J. Vasseur, "Polyphenol production in Crataegus tissue cultures (hawthorn)," in Biotechnology in 
Agriculture and Forestry: Medicinal and Aromatic Plants XII, T. Nagata and Y. Ebizuka, Eds., pp. 23-49, Springer, Berlin, Germany, 2002.

[53] A. Djeridane, M. Yousfi, B. Nadjemi, D. Boutassouna, P. Stocker, and N. Vidal, "Antioxidant activity of some algerian medicinal plants extracts containing phenolic compounds," Food Chemistry, vol. 97, no. 4, pp. 654-660, 2006.

[54] M. Jerez, A. Selga, J. Sineiro, J. L. Torres, and M. J. Núñez, "A comparison between bark extracts from Pinus pinaster and Pinus radiata: antioxidant activity and procyanidin composition," Food Chemistry, vol. 100, no. 2, pp. 439-444, 2007.

[55] E. Yamazaki, M. Inagaki, O. Kurita, and T. Inoue, "Antioxidant activity of Japanese pepper (Zanthoxylum piperitum DC.) fruit," Food Chemistry, vol. 100, no. 1, pp. 171-177, 2007.

[56] C. F. Duffy and R. F. Power, "Antioxidant and antimicrobial properties of some Chinese plant extracts," International Journal of Antimicrobial Agents, vol. 17, no. 6, pp. 527-529, 2001.

[57] K. Güven, E. Yücel, and F. Cetintaş, "Antimicrobial activities of fruits of Crataegus and Pyrus species," Pharmaceutical Biology, vol. 44, no. 2, pp. 79-83, 2006.

[58] M. T. Gatto, S. Falcocchio, E. Grippa et al., "Antimicrobial and anti-lipase activity of quercetin and its C2-C16 3-O-acyl-esters," Bioorganic and Medicinal Chemistry, vol. 10, no. 2, pp. 269-272, 2002.

[59] D. Wu, Y. Kong, C. Han et al., "d-Alanine:d-alanine ligase as a new target for the flavonoids quercetin and apigenin," International Journal of Antimicrobial Agents, vol. 32, no. 5, pp. 421-426, 2008.

[60] A. P. Pereira, I. C. F. R. Ferreira, F. Marcelino et al., "Phenolic compounds and antimicrobial activity of olive (Olea europaea L. Cv. Cobrançosa) leaves," Molecules, vol. 12, no. 5, pp. 11531162, 2007.

[61] S.-C. Wu, G.-C. Yen, B.-S. Wang et al., "Antimutagenic and antimicrobial activities of pu-erh tea," Food Science and Technology, vol. 40, no. 3, pp. 506-512, 2007.

[62] W.-Y. Zhang, H.-Q. Liu, K.-Q. Xie et al., "Procyanidin dimer B2 [epicatechin-( $4 \beta-8)$-epicatechin] suppresses the expression of cyclooxygenase-2 in endotoxin-treated monocytic cells," Biochemical and Biophysical Research Communications, vol. 345, no. 1, pp. 508-515, 2006.

[63] Y. Han, "Rutin has therapeutic effect on septic arthritis caused by Candida albicans," International Immunopharmacology, vol. 9, no. 2, pp. 207-211, 2009.

[64] T.-S. Jeong, E.-L. Hwang, H.-B. Lee et al., "Chitin synthase II inhibitory activity of ursolic acid, isolated from Crataegus pinnatifida," Planta Medica, vol. 65, no. 3, pp. 261-263, 1999. 

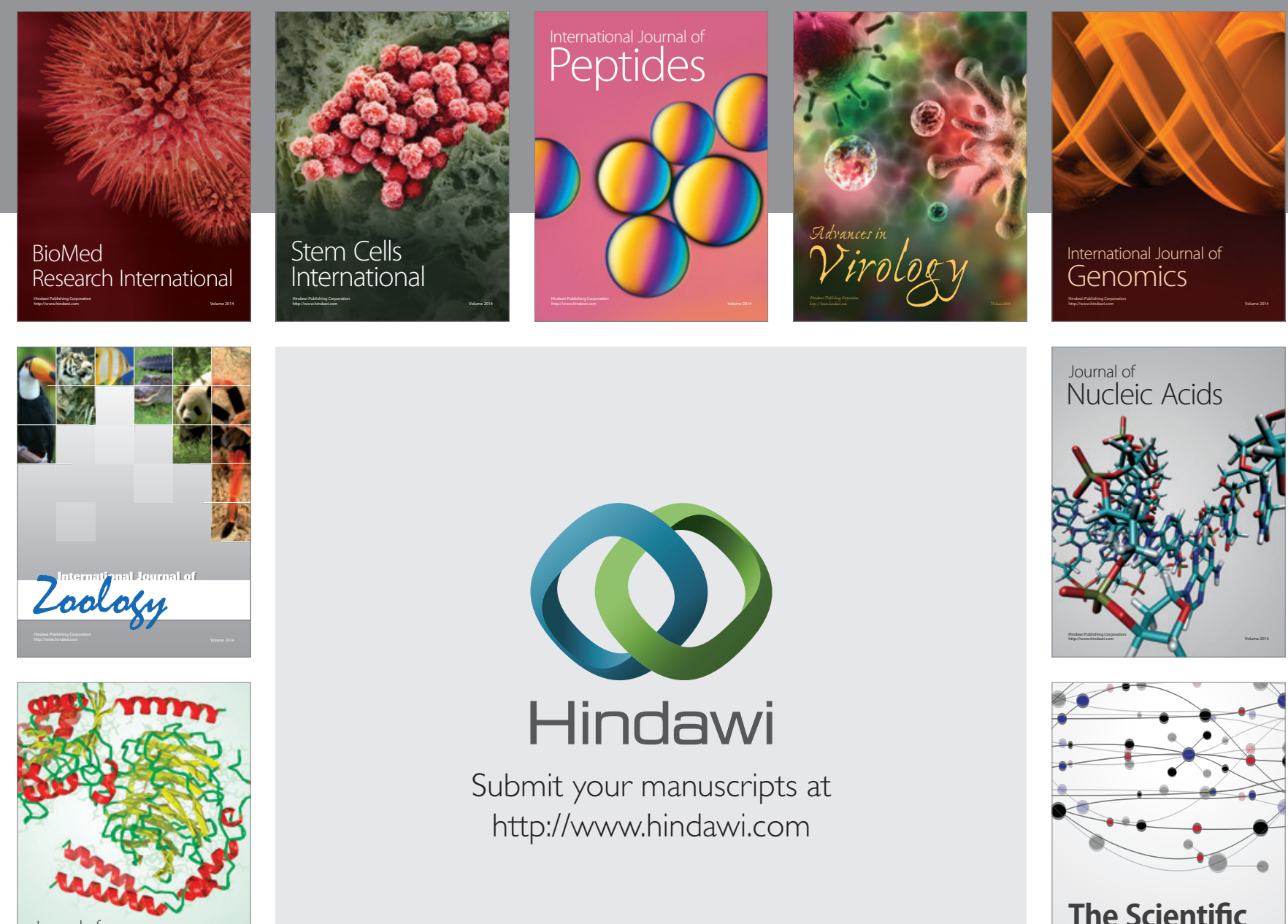

Submit your manuscripts at

http://www.hindawi.com

Journal of
Signal Transduction
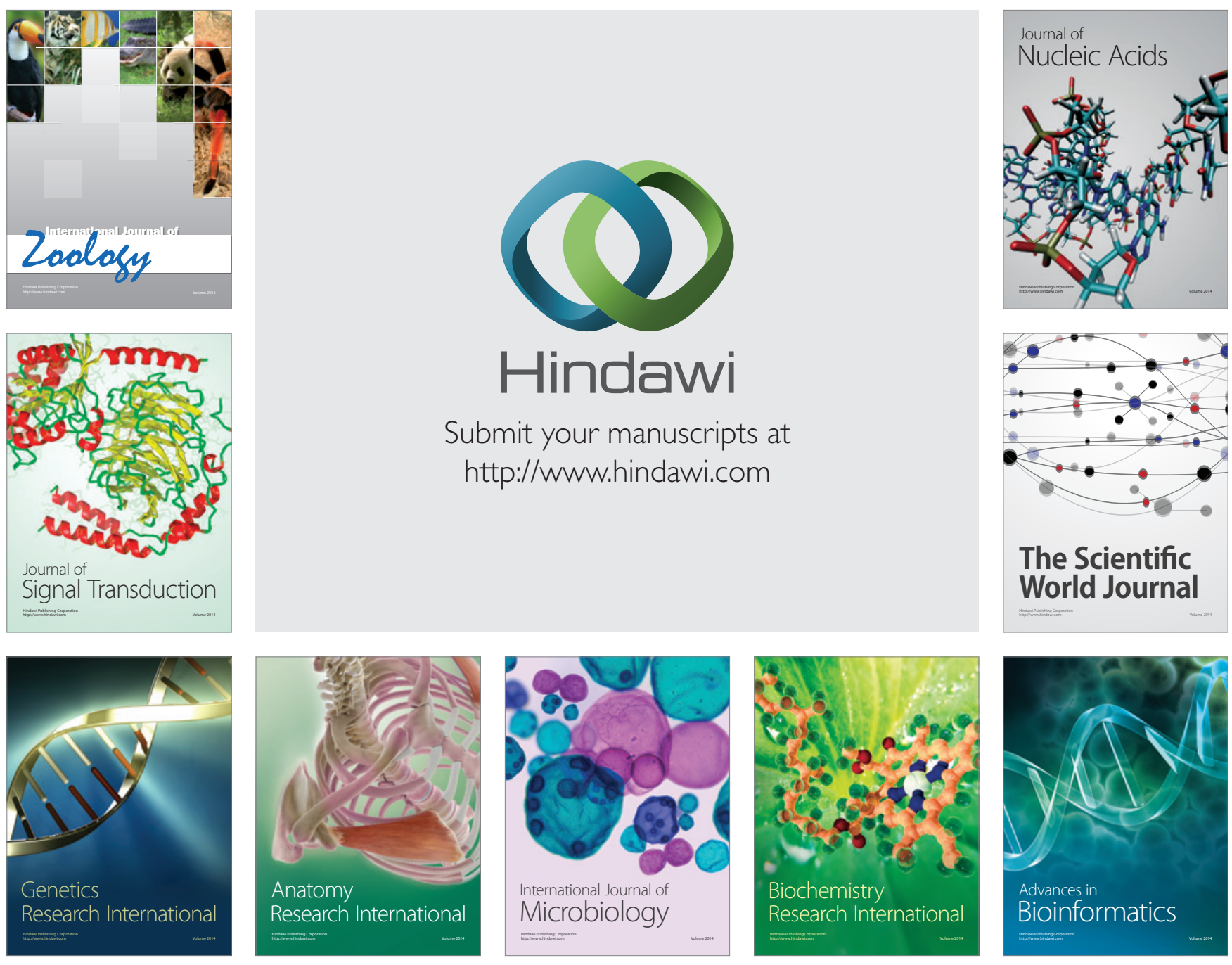

The Scientific World Journal
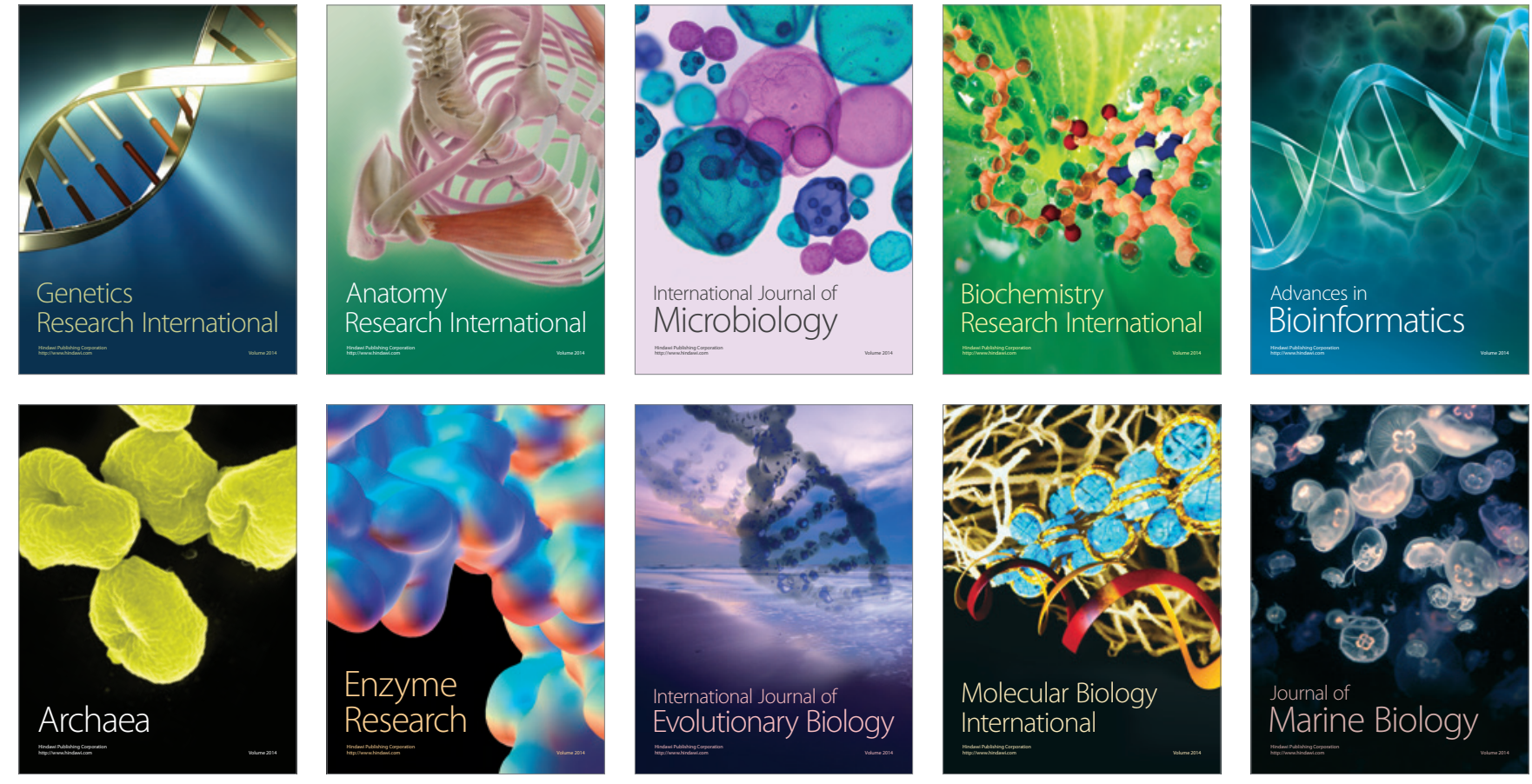